\title{
Calcitonin-negative primary neuroendocrine tumor of the thyroid (nonmedullary) in a dog
}

\author{
E.A. Soler Arias ${ }^{1, *}$, V.A. Castillo ${ }^{1}$ and M.E. Caneda Aristarain ${ }^{2}$ \\ ${ }^{1}$ Hospital Escuela, Unidad de Endocrinología, Area de Clínica Médica de Pequeños Animales, Fac. de Ciencias \\ Veterinarias, UBA, Av. Chorroarín 280, Ciudad Autónoma de Buenos Aires, Argentina \\ ${ }^{2}$ Alumna de Programa de Investigación. Fac. de Ciencias Veterinarias, UBA, Chorroarín 280, Ciudad Autónoma de \\ Buenos Aires, Argentina
}

\begin{abstract}
The Calcitonin-negative neuroendocrine tumor of the thyroid (CNNET) or "nonmedullary" in humans is a rare tumor that arises primarily in the thyroid gland and may be mistaken for medullary thyroid carcinoma; it is characterized by the immunohistochemical (IHC) expression of neuroendocrine markers and the absence of expression for calcitonin. An Argentine dogo bitch showed a solid, compact thyroid tumor, which was IHC negative for the expression of calcitonin, carcinoembryonic antigen, thyroglobulin and S100 protein, and positive for synaptophysin and cytokeratin AE1-AE3. The Ki-67 proliferation index was low. We cite this case not only because it is the first case report of calcitonin-negative primary neuroendocrine tumor of the thyroid in dogs but also because we want to highlight the diagnostic importance of IHC in this regard.
\end{abstract}

Keywords: Calcitonin-negative, Immunohistochemistry, Ki-67, Medullary thyroid carcinoma, Neuroendocrine.

\section{Introduction}

With the exception of the medullary thyroid carcinoma (MTC), other neuroendocrine tumors (NETs) can rarely be seen in the human thyroid gland (Nakazawa et al., 2014); among these tumors we can cite the paraganglioma $(\mathrm{Pg})$, the hyalinising trabecular tumor, the metastatic neuroendocrine tumor to the thyroid gland and the intrathyroid parathyroid adenoma or tumor. Several reports have recently postulated a rare calcitonin-negative NET of the thyroid or nonmedullary (CNNET) as a new entity based on its IHC features: negative staining for calcitonin (CT) and carcinoembryonic antigen (CEA) and positive staining for neuroendocrine markers Chromagranin A (CGA) and Synaptophysin (Syn) (Ismi et al., 2014; Kim et al., 2015; Chernyavsky et al., 2011; Zengguang et al., 2016).

These tumors pose a challenge in terms of diagnosis due to their histopathological similarities to MTC and the corresponding IHC expression of neuroendocrine markers. Several reports on MTC in dogs have been published (Campos et al., 2014; Patnaik et al., 2002). However, as per the best knowledge of authors, this would be the first CNNET case to have ever been published.

\section{Case details}

A 8-year old spayed, Argentine dog was presented to the Endocrinology Service Unit at our hospital. The patient presented a cervical region tumor, located in the left thyroid lobe's projection area. The ultrasound revealed a 7 x $4.5 \mathrm{~cm}$ hyperechoic, well-defined, multilobed mass with moderate peripheral and intratumoral vascularization; the right thyroid lobe had preserved shape and size with a slightly increased heterogeneous echogenicity. The regular blood test and the endocrine/biochemical testing (TSH: $0.22 \mathrm{ng} / \mathrm{ml}$, reference value $0.03-0.35 \mathrm{ng} / \mathrm{ml}$; T4f: $0.98 \mathrm{ng} / \mathrm{dl}$, reference value 0.6 - $1.6 \mathrm{ng} / \mathrm{dl}$; PTH: $1.7 \mathrm{pmol} / \mathrm{l}$, reference value $0.6-3.55 \mathrm{pmol} / \mathrm{l}$ ) showed all results within the reference values, with the exception of the alkaline phosphatase: 635UI/l (Reference value up to 250UI/1).

The exact nature of mass could not be determined by cytology, however, it was indicative of malignant. A left hemithyroidectomy was performed under suspicion of thyroid carcinoma, after ruling out other thoracic and abdominal neoplasias by means of X-rays and ultrasonography. The clinical stage of the thyroid gland tumor (TNM) was: T3b ( $>5 \mathrm{~cm}$, fixed), N0 (no evidence of regional lymph node involvement), M0 (no evidence of distant metastasis) (Owen, 1980). During the surgery, local extension of the tumor to sternothyroid muscle and the esophagus wall was observed. No evidence of invasion to the regional lymph node was detected (Fig. 1A). The neoplastic cells were arranged in nests surrounded by a moderate fibrovascular stroma with large nuclei and abundant, slightly acidophilic cytoplasm. At that moment, the histological diagnosis of neoplasia was thyroid carcinoma subclassified as the solid, compact type. 


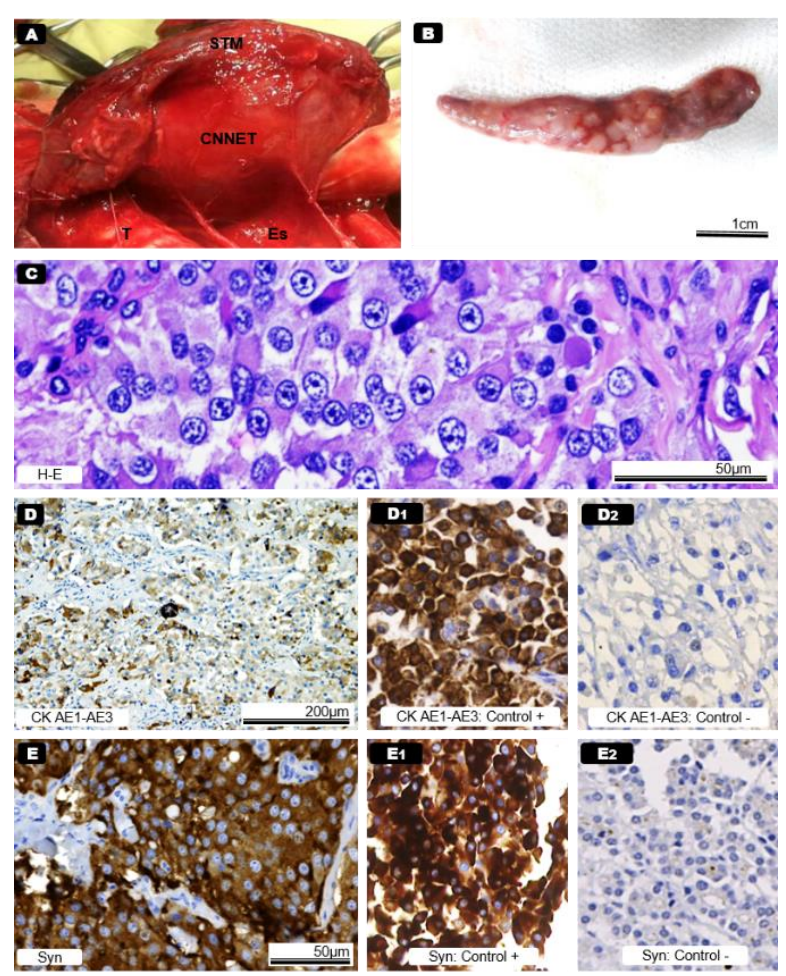

Fig. 1. (A-E): Calcitonin-negative primary neuroendocrine tumor of the thyroid (CNNET). (A): CNNET aspect during surgery with invasion to esophagus (Es) and sternothyroid muscle (STM); T: trachea. (B): Right thyroid lobe (necropsy); notice the whitish, mottled look. (C): CNNET microscopic aspect with hematoxylin and eosin staining (H-E). Bar = $50 \mu \mathrm{m}$. (D): CNNET immunohistochemical positive staining

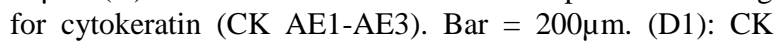
AE1-AE3 positive control (Liver tissue). (D2): CK AE1-AE3 negative control (Liver tissue). (E): CNNET immunohistochemical positive staining for synaptophysin (Syn). Bar $=50 \mu \mathrm{m}$. (E1): Syn positive control (medullar thyroid carcinoma). (E2): Syn negative control (thyroid follicular cells).

Tumor cells stained positive for cytokeratin (CK) AE1AE3 and for the neuroendocrine marker Syn, and they stained negative for thyroglobulin (Tg), CT, CEA and $\mathrm{S} 100$ protein $(\mathrm{S} 100)$. The $\mathrm{Ki} 67$ proliferation index was low. Based on IHC results it was conclude that mass was neuroendocrine tumor of thyroid gland. The postsurgical evolution was as satisfactory as the biochemical and imagining follow-ups performed eight and sixteen weeks after the surgery.

Regrettably, the animal developed gastric dilationvolvulus and died. The necropsy revealed no evidence of tumors. The right thyroid lobe, with preserved shape and size, displayed several whitish foci, which were firm when dissected (Fig. 1B) and histopathological examinations revealed similar features to those of the thyroid tumor located in the left lobe. In conclusion, the patient showed a calcitonin-negative primary neuroendocrine tumor of the thyroid.
Immediately after the surgery, the surgical specimen was fixed in $10 \%$ buffered formalin and embedded in paraffin blocks. $3 \mu \mathrm{m}$-thin sections were cut and stained with hematoxylin and eosin.

The IHC staining and control (Table 1) were perfomed by means of the Avidin-Biotin Complex (ABC) and the 3.3'-diaminobenzidine chromogen (DAB). The images were taken with a Leica DC160 digital camera connected to a trinocular microscope (Leica DM4000B led).

Quantification of the staining IHC was performed semiquantitatively through the percentage of tumor cells stained positively/cells per field. Staining intensity was subjectively classified as mild, moderate and intense. Macroscopically, the entire left lobe of the thyroid was affected by neoplasia, which was well-defined by a moderately vascularized, thin capsule. The cutting surface showed solid-cystic features with hard, yellowish consistency and dark-colored, doughy areas. Histologically, the tumor was surrounded a thin capsule fibrous peripheral.

In some sections, the invasion of neoplastic cells into the striated muscle was visible. Adittionaly, atrophic thyroid follicles were observed, as well as a few healthy follicles trapped in neoplasia. The tumor was composed of polyhedral cells with moderate pleomorphism and anaplasia, large and round nuclei, prominent nucleoli and acidophilic cytoplasm. No mitotic figures were discerned. The cells were arranged in the form of solid nests supported in by a moderate fibrovascular stroma (Fig. 1C). IHC data is summarized in Table 2.

The cytoplasm of tumor cells (20\% of the field) was moderately positive for CK AE1-AE3 (Fig. 1D), whereas $100 \%$ of the cells were intensely positive for Syn (Fig. 1E). "With the exception of a few healthy follicles trapped in neoplasia," it stained negative for Tg (Fig. 2A), CT (Fig. 2B), CEA and S100. The determination of the nuclear antigen Ki-67 was 3\%, which is deemed as low (Fig. 2C).

\section{Discussion}

This report depicts the contribution of IHC to the definitive diagnosis of a rare NET, which primarily arises in the thyroid gland, and of which, to the authors' knowledge, there are no prior references in veterinary bibliography. Upon review of human literature, some case reports were found displaying similar IHC features. Those cases were initially referred to as "atypical medullary thyroid carcinoma" (Schmid and Ensinger, 1998), then, "calcitonin-negative medullary thyroid carcinoma" (Wang et al., 2008) and finally, "Calcitonin-negative neuroendocrine tumor of the thyroid" or nonmedullary (CNNET) (Chernyavsky et al., 2011). The use of Syn helped determining the neuroendocrine origin of our case. The procedure can also be performed by means of CGA or Neuron-specific enolase (ENS), even though the latter is less specific. 
Table 1. Antibodies used in immunohistochemistry.

\begin{tabular}{|c|c|c|c|c|}
\hline Primary antibody & Type of antibody & Dilution & Positive control & Negative control \\
\hline $\mathrm{Tg}$ & $\begin{array}{l}\text { Mouse monoclonal } \\
\text { Santa Cruz Biotechnology }\end{array}$ & $1: 50$ & $\begin{array}{l}\text { Normal thyroid } \\
\text { follicular cells } \\
\text { in dogs }\end{array}$ & $\begin{array}{l}\text { MTC parafollicular } \\
\text { cells in dogs. }\end{array}$ \\
\hline $\mathrm{CT}$ & $\begin{array}{l}\text { Rabbit polyclonal } \\
\text { Biolaboratorio Dako }\end{array}$ & $1: 400$ & $\begin{array}{l}\text { MTC (previously } \\
\text { reported) }\end{array}$ & $\begin{array}{l}\text { Normal thyroid } \\
\text { follicular cells in dogs. }\end{array}$ \\
\hline CEA & $\begin{array}{l}\text { Mouse monoclonal } \\
\text { Biolaboratorio Dako }\end{array}$ & $1: 50$ & $\begin{array}{l}\text { Colon (epithelial } \\
\text { cells) }\end{array}$ & Colon (epithelial cells). \\
\hline Syn & $\begin{array}{l}\text { Mouse monoclonal } \\
\text { Santa Cruz Biotechnology }\end{array}$ & $1: 50$ & $\begin{array}{l}\text { MTC parafollicular } \\
\text { cells in dogs }\end{array}$ & $\begin{array}{l}\text { Normal thyroid } \\
\text { follicular cells in dogs }\end{array}$ \\
\hline CK AE1-AE3 & $\begin{array}{l}\text { Mouse monoclonal } \\
\text { Biolaboratorio Dako }\end{array}$ & $1: 100$ & Liver tissue & Liver tissue. \\
\hline S100 & $\begin{array}{l}\text { Rabbit polyclonal } \\
\text { Biolaboratorio Dako }\end{array}$ & $1: 200$ & $\begin{array}{l}\text { Peripheral Nervous } \\
\text { Tissue }\end{array}$ & $\begin{array}{l}\text { Peripheral nervous } \\
\text { tissue. }\end{array}$ \\
\hline MIB-1 & $\begin{array}{l}\text { Mouse monoclonal } \\
\text { Biolaboratorio Dako }\end{array}$ & $1: 75$ & Nodal lymphoma & $\begin{array}{l}\text { Non tumoral thyroid } \\
\text { tissue. }\end{array}$ \\
\hline
\end{tabular}

Table 2. Immunohistochemical profile of calcitonin-negative neuroendocrine tumor of the thyroid, previously reported.

\begin{tabular}{|c|c|c|c|c|c|c|c|c|c|}
\hline \multirow{2}{*}{ Author } & \multicolumn{8}{|c|}{ Immunohistochemistry } & \multirow[t]{2}{*}{ Nomenclature } \\
\hline & $\mathrm{Tg}$ & CT & CEA & Syn & CGA & $\mathrm{S} 100$ & CK & MIB-1 & \\
\hline $\begin{array}{l}\text { Chernyavsky et } \\
\text { al., } 2011\end{array}$ & + & - & $\mathrm{Np}$ & + & W & $\mathrm{Np}$ & + & $\mathrm{Np}$ & $\begin{array}{l}\text { Calcitonin-negative neuroendocrine } \\
\text { tumor of the thyroid. }\end{array}$ \\
\hline $\begin{array}{l}\text { Ismi et al., } \\
2014\end{array}$ & - & - & - & + & + & - & $\mathrm{Np}$ & $70 \%$ & $\begin{array}{l}\text { Calcitonin-negative neuroendocrine } \\
\text { tumor of the thyroid. }\end{array}$ \\
\hline $\begin{array}{l}\text { Kim et al., } \\
2015\end{array}$ & + & - & - & + & + & $\mathrm{Np}$ & - & $\mathrm{Np}$ & $\begin{array}{l}\text { Calcitonin-negative neuroendocrine } \\
\text { tumor of the thyroid with follicular } \\
\text { cell origin. }\end{array}$ \\
\hline $\begin{array}{l}\text { Zengguang et } \\
\text { al., } 2016\end{array}$ & - & - & $\mathrm{Np}$ & + & + & $\mathrm{Np}$ & $\mathrm{Np}$ & $40 \%$ & $\begin{array}{l}\text { Thyroid neuroendocrine cancer } \\
\text { accompanied with papillary } \\
\text { carcinoma. }\end{array}$ \\
\hline $\begin{array}{l}\text { Gonzalez } \\
\text { Alcolea et al., } \\
2015\end{array}$ & - & - & $\mathrm{Np}$ & + & $\mathrm{Np}$ & $\mathrm{Np}$ & $\mathrm{Np}$ & $\mathrm{Np}$ & $\begin{array}{l}\text { Calcitonin-negative nonmedullary } \\
\text { neuroendocrine tumor of the } \\
\text { thyroid. }\end{array}$ \\
\hline $\begin{array}{l}\text { Nakazawa et } \\
\text { al., } 2014\end{array}$ & - & - & - & + & + & $\mathrm{Np}$ & + & $2 \%$ & $\begin{array}{l}\text { C-cell-derived calcitonin-free } \\
\text { neuroendocrine carcinoma of the } \\
\text { thyroid } \bullet \text { CGRP. }\end{array}$ \\
\hline $\begin{array}{l}\text { Soler et al., } \\
2016^{*}\end{array}$ & - & - & - & + & $\mathrm{Np}$ & - & + & $3 \%$ & $\begin{array}{l}\text { Calcitonin-negative primary } \\
\text { nonmedullary neuroendocrine tumor } \\
\text { of the thyroid }\end{array}$ \\
\hline
\end{tabular}

W: Weak.

Np: Not performed.

*: This report.

-CGRP: positive for the calcitonin gene-related peptide (CGRP).

Regarding the NETs that may affect the thyroid gland, the MTC certainly is the most prevalent tumor both in dogs and in humans (Campos et al., 2014; Kim et al., 2015).

However, its highly variable histological features call for the use of IHC with its most specific marker, the CT, coupled with CEA. The latter is not specific, it has a major role in the diagnosis of poorly differentiated MTC, though. (Ismi et al., 2014; Schmid, 2015). In our case, the tumor cells were negative for CT and CEA. Consequently, MTC was ruled out.
The other NETs rarely affect the thyroid. Even though it has not been deemed as a primary thyroid tumor, among the rare NETs we find the Pg (Nakazawa et al., 2014), which is typically composed of two cell types: the principal cells, which stain positive for neuroendocrine markers but negative for CKAE1/AE3, Tg, CT, CEA and PTH; and the sustentacular cells, which stain positive for $\mathrm{S} 100$ protein and are located at the periphery of tumor nests ( $\mathrm{Yu}$ et al., 2013). Therefore, the lack of S100 expression and the presence of $\mathrm{CK}$ expression in our patient ruled out the $\mathrm{Pg}$. 


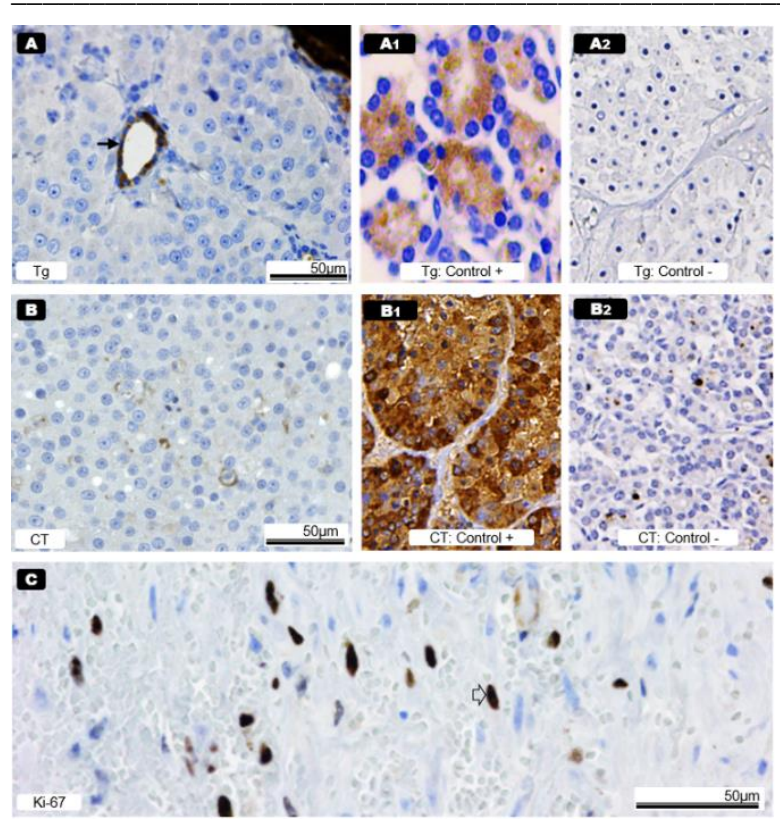

Fig. 2. (A): CNNET immunohistochemical negative staining for thyroglobulin (Tg); thyroid follicle trapped in neoplasia with positive staining for $\mathrm{Tg}$ (arrow). (A1): $\mathrm{Tg}$ positive control (Thyroid follicular cells). (A2): Tg negative control (Thyroid parafollicular cells-medullar thyroid carcinoma). (B): Immunohistochemical negative staining for calcitonin (CT). (B1): CT positive control (medullary thyroid carcinoma). (B2): CT negative control (thyroid follicular cells). (C): Nuclear antigen Ki-67 staining in tumor cells with the monoclonal antibody MIB I (arrow); proliferation index of $3 \%$. Bar $=50 \mu \mathrm{m}$.

Nevertheless, S100 has been described in a rare type of MTC referred to as "MTC like-paraganglioma" (Schmidt, 2015; Yu et al., 2013). In the dog, S100 was also expressed in five MTC (Patnaik and Lieberman, 1991).

The hyalinizing trabecular tumor is another human thyroid tumor with relative neuroendocrine staining. However, these tumors are also positive for $\mathrm{Tg}$ and present a unique membranous expression of Ki-67. Thus, it was easily ruled out from our case (Brunas et al., 2005; Yu et al., 2013).

The intrathyroid parathyroid adenoma and carcinoma are NETs (Li et al., 2014) whose initial diagnosis is established by means of the concentrations elevated the plasmatic PTH (primary hyperparathyroidism), being both the histopathology as the IHC merely confirmatory (Li et al., 2014). In connection with our case, we were not able to carry out the PTH staining. The clinical and biochemical diagnosis of primary hyperparathyroidism had already been excluded, though.

All the other types of thyroid NETs having been ruled out, there is only one option left: the metastasis of an unknown primary tumor, which human medicine calls "neuroendocrine tumor of unknown primary site"
(Gonzalez Alcolea et al., 2015). The data gathered from the necropsy concluded that it was a primary NET of the thyroid and that it affected both lobes of the thyroid. Hence, our final diagnosis was: calcitonin-negative primary neuroendocrine tumor of the thyroid (nonmedullary), an entity described by Chernyavsky et al. (2011), which had not been reported in dogs so far. Other cases of similar IHC features have arisen in human medicine in the recent years (Table 2). Only two reports stated that the tumor had also been positive for Tg. Thus, their authors implied that those tumors might have a follicular origin (Kim et al., 2015; Chernyavsky et al., 2011).

Nakazawa et al. (2014) described a CNNET with positive staining for the calcitonin gene-related peptide (CGRP), which proved it originated in parafollicular cells, where both CGRP and CT are coexpressed. This confirms the existence of an unusual type of MTC. In a study performed in dogs, six MTC were positive for CGRP and only four of them showed positivity for CT. These findings indicate that CGRP may be a better marker for the diagnosis of MTC in dogs than CT (Leblanc et al., 1991). In that study, CEA levels were not measured. While in one of the cases the expression of CGRP was only observed in the parafollicular cells trapped in neoplasia, in the second case the expression was mild. Consequently, we suggest CGRP measurements should be made in a larger group of MTC cases in dogs.

Regarding neoplasia malignancy, the presence of local invasion to the capsule, soft tissues and striated muscle were sufficient evidence to confirm its malignant behavior. Nevertheless, both the low Ki-67 and mitotic index matched a low-grade neuroendocrine tumor of the thyroid in histopathology (Klimstra et al., 2010). This fact highlights the importance of linking the findings deriving from surgery, histopathology and IHC so as to properly stage the tumor.

In conclusion, many of the thyroid tumors cannot be correctly diagnosed without the routine use of IHC. The implementation of CGRP and CEA markers to differentiate atypical MTC from CNNET is highly recommended. The direct effect of specific identification and differentiation of each type of thyroid carcinoma, as well as the search for new molecular markers with a therapeutic targets will facilitate the provision of more realistic prognosis, based on recurrence and survival rates applicable to upcoming cases.

\section{Conflict of interest}

The authors declare that there is no conflict of interest.

\section{References}

Brunas, O., García, M.G., Sarancone, S., Novelli, J.L. 2005. Adenoma trabecular hialinizante: un tumor poco frecuente de la glandula tiroides. Glán Tir 
Paratir 14:35-38.

Campos, M., Ducatelle, R., Rutteman, G., Kooistra, H.S., Duchateau, L., Rooster, de H., Peremans, K. and Daminet, S. 2014. Clinical Pathologic, and Immunohistochemical Prognostic Factors in Dogs with Thyroid Carcinoma. J. Vet. Intern. Med. 28, 1805-1813.

Chernyavsky, V.S., Farghani, S., Davidov, T., Ma, L., Barnard, N., Amorosa, L.F. and Trooskin, S.Z. 2011. Calcitonin-negative neuroendocrine tumor of the thyroid: a distinct clinical entity. Thyroid 21, 193-196.

Gonzalez Alcolea, N., Artés Caselles, M., Laiz Diez, B., Jiménez Cubedo, E., Calvo Espino, P., González Plo, D., Rivera Bautista, J.A. and Sánchez Turrión, V. 2015. Carcinoma neuroendocrino de tiroides calcitonina-negative (No medular). A propósito de un caso. Cir Esp, 93 (Espec congr), 322.

Ismi, O., Arpaci, R.B., Berkesoglu, M., Dag, A., Sezer, E., Bal, K.K. and Vayisoglu, Y. 2014. Calcitoninnegative neuroendocrine tumor of thyroid gland mimicking anaplastic carcinoma: an unusual entity. Gland surg. 4(4), 344-349.

Kim, G.Y., Park, C.Y., Cho, C.H., Park, J.S., Jung, E.D. and Jeon, E.J. 2015. A Calcitonin-Negative Neuroendocrine Tumor Derived from Follicular Lesions of the Thyroid. Endocrinol. Metab. 30, 221225.

Klimstra, D.S., Modlin, I., Coppola, D., Lloyd, R.V. and Suster, S. 2010. The Pathologic Classification of Neuroendocrine Tumors A Review of Nomenclature, Grading, and Staging Systems. Pancreas 39, 707-712.

Leblanc, B., Parodi, A.L., Lagadic, M., Hurtrel, M. and Jobit, C. 1991. Immunocytochemistry of Canine Thyroid Tumors. Vet. Pathol. 28, 370-380.

Li, J., Chen, W. and Liu, A. 2014. Clinicopathologic features of parathyroid carcinoma: a study of 11 cases with review of literature. Zhonghua Bing Li Xue Za Zhi. 43(5), 296-300.
Nakazawa, T., Teijeiro, C., Vinagre, J., Soares, P., Rousseau, E., Eloy, C. and Sobrinho-Simões, M. 2014. C-cell-Derived Calcitonin-Free Neuroendocrine Carcinoma of the Thyroid: The diagnostic Importance of CGRP Immunoreactivity. Int. J. Surg. Pathol. 22(6), 530-535.

Owen, L.N. 1980. TNM Classifications of tumor in domestic animals. World Health Organization, Veterinary Public Health Unit WHO, Collaborating Center for Comparative Oncology. First Edition Geneve, pp: 51-52.

Patnaik, A.K., Ludwig, L.L. and Erlandson, R.A. 2002. Neuroendocrine carcinoma of the Nasopharynx in a dog. Vet. Pathol. 39, 496-500.

Patnaik, A.K. and Lieberman, P.H. 1991. Gross, Histologic, Cytochemical, and Immunocytochemical Study of Medullary Thyroid Carcinoma in Sixteen Dogs. Vet. Pathol. 28, 223233.

Schmid, K.W. and Ensinger, C. 1998. "Atypical" medullary thyroid carcinoma with little or no calcitonin expression. Virchows Arch. 433, 209215.

Schmid, K.W. 2015. Histopathology of C cells and Medullary Thyroid Carcinoma. Recent Results Cancer Res. 204, 41-60.

Wang, T.S., Ocal, I.T., Sosa, J.A., Cox, H. and Roman, S. 2008. Medullary thyroid carcinoma without marked elevation of calcitonin: a diagnostic and surveillance dilemma. Thyroid 18, 889-894.

Yu, B.H., Sheng, W.Q. and Wang, J. 2013. Primary paraganglioma of thyroid gland: A clinicopathologic and immunohistochemical analysis of three cases with a review of the literature. Head Neck Pathol. 7, 373-380.

Zengguang, L., Jin, M., Su, C., Ren, J., Wan, F., Guan, Q., Miao, Z., Chen, G. and Wang, G. 2016. Thyroid neuroendocrine cancer accompanied with multiple papillary thyroid carcinomas: a case report. Int. J. Clin. Exp. Pathol. 9(2), 2396-2401. 